the Yankton Sioux, arrived and commenced the removal of the Indians to their reservation, near Fort Randal. As Sioux City was the gateway to Dakota territory, her citizens became much interested in the settlement and territorial organization of the territory. It was in the summer of 1858, soon after the territory was opened for settlement, that a number of persons from Sioux City, headed by a few politicians, who, no doubt, were yearning for a fat appointment in the territory, crossed the Big Sioux river into the territory and held a meting, petitioning congress for a territorial organization, in order to make congress believe that there were many citizens in the territory, and that the establishment of a territorial government was necessary. To do this, they petitioned early and petitioned late. The petition was forwarded to $\mathrm{H}^{\mathrm{a}}$ ashington, showing a very large number of citizens - many of them, however, had never seen the territory. This proved a failure. However, the territory commenced filling up rapidly; many citizens of Iowa moved in and took claims.

The territory was not organized until the $2 \mathrm{~d}$ of March, 1861. In the first legislature were many of the pioneer settlers of northwestern Iowa. The territory is now rapidly filling up by a hardy and industrious class of citizens, who are rapidly developing the richness of her soil and commercial interests, which are now giving her a world-wide fame, and will soon number her among the leading countries of the northwest.

[TO BE CONTINUED.]

\title{
NOTES ON THE EARLY HISTORY OF POTTAWATTAMIE OOUNTY.
}

BY D. O. BLOOMER, COUNOIL BLUFFs.

THE county of Pottawattamie is now the largest in the state. Its greatest length from east to west is forty-four miles, and it has a uniform width, from north to south, of 
twenty-four miles. It contains twenty-four full congressional townships, each six miles square, and seven fractional townships, comprising nine hundred and sixty square miles, and six hundred and fourteen acres of superficial area.

It is washed on the west by the Missouri river, the course of which is here, as throughout its entire length, very tortuous, but as it only touches the eastern bluffs at a single point within the county, the broad bottom lands amid which it flows are thrown on its eastern side, and therefore embraced within its limits. The valley is from three to seven miles in width, its narrowest point being at Council Bluffs, and its widest, near the north-west corner of the county.

The soil of this valley is, it is believed, unsurpassed in fertility by any in the world. Its depth and strength is so great that it seems almost inexhaustible.

Skirting the valley on the east are the famed bluffs of the Missouri, from fifty to three hundred feet in height, composed of a mixture of sand and clay, and, except in a very few places, entirely destitute of rock of any description. Piled up in every conceivable form, yet generally presenting rounded summits, they present to the beholder a striking and not unpleasant appearance. In the summer, when clothed with verdure, and played upon by the sun's light and shadow, they are really beautiful; and their summits afford a fine view of the country, for miles, to the north, west, and south.

Eastward of the bluffs the county, for a few miles, is badly broken up in ridges, but beyond these come the broad and elevated prairies that roll off to the eastward in successive elevations and depressions, resembling, in appearance, the long swells of the ocean. Numerous streams traverse the county, generally in a south-westerly direction, until they unite with the Missouri. The soil is exceedingly fertile and the climate healthy and invigorating.

It is not my purpose to enter upon an elaborate description of the county, but simply to note down in a few paragraphs, some incidents connected with its early history, which, like that of the entire western country, extends far back beyond 
any written memorials. In common with all the vast prairie regions of North America, it had been roamed over for centuries, before the arrival of the European, by the native aborigines, who here pursued the pleasures, the excitement, and the dangers of the chase, unmolested by the crack of the rifle.

It is, however, certain that the Missouri had been traversed several years previous to the close of the last century, from its mouth far up towards, if not, in fact, to the foot of the Rocky mountains, by white men in pursuit of skins and furs, and for the purpose of trade with the Indians.

The expedition of Lewis and Clark, in 1804, was the first organized attempt, on the part of the government, to explore these vast national doniains - the seat of future wealth and greatness. Starting from St. Louis, these explorers passed up the great river until they finally reached its source, and crossed the mountains that separate it from the Oregon, which they reached and followed to its union with the Pacific. The Indians flocked in from all sides to inspect their boats and equipments, and solicit presents. The commanders of the expedition held frequent councils, or talks, with them, and one of these friendly meetings took place at a point near the northwestern corner of the present county of Pottawattamie, which was thenceforward designated as the Council Bluffs. A fort was afterwards erected by the United States government, at or near this place, and the name itself, after having been a noted locality for fifty years on all the maps of the great northwestern territory, was given in 1853 , by special act of the General Assembly of Iowa, to the county seat of Pottawattamie county.

Meautime the dealers in furs continued to ply their profitable but dangerous calling, and for the first forty or fifty years of the present century, their agents and servants, many of them Frenchmen, or the descendants of Frenchmen by Indian women, continued each season to drag or push their keel boats or canoes up against the swift current 'of the river, and when they had disposed of their cargoes of Indian goods and presents in exchange for furs and peltries, to float leisurely 
down stream with them, to their starting point at St. Louis. Sev. eral of these old traders are still found in the country. One of them, Mr. Francis 'Guittar, now resides in the city of Council Bluffs, and he informed the writer of these notes a few days since, that he recollected encamping forty-four years ago (1827) with his companions de voyage, at a point under the bluffs, now situated in the most populous part of the city. These traders had their small camping places, or trading points, along the river. One of these was situated, as early as 1824, at what was, in those days, known as 'Hart's bluffs, from a Frenchman who had located there, and which is now found, on inquiry, to have been at a place in the city of Council' Bluffs, known as Mynster's spring, from a beautiful and abundant flow of water that gushes out from the bluffs at that point. Farther down the river, and near the south-west corner of the county, was another noted place of rendezvous, alike for Indians and traders, known as Traders'Point. Peter A. Sarpy, a prominent character in all this region in those early days, had his head-quarters at this point, and here he amassed considerable wealth, and, like many other Frenchmen, took a wife from among the Indian women of the country.

In 1838 the government removed the Pottawattamie Indians from the Platt purchase in Missonri, to the southwestern part of Iowa, with their head-quarters in Pottanattamie county, at the place where the city of Council Bluffs is now situated. - With them came a number of agents, artificers, and employes. Among the latter was Davis Hardin, who filled the post of farmer for the Indians. He landed at Trader's Point, sometime during the summer, and brought with him his wife and seven sons, two of whom, Richard and Martin D., are still residents, and the oldest white inhabitants of western Iowa.

In 1839, two companies of United States troops came up the river and built a fort, or block house, in what is now the eastern part of the city of Council Bluffs. About the same time two Cátholic missionaries came to the same place, and established a mission among the Indians, using the block 
house for their religions meetings, and erecting a dwelling honse of logs for their own accommodation. As late as 1855, the former building was still standing, surmounted by a rude cross, an emblem of the faith and zeal of these pious pioneers of Christianity in this vast region. They also established a burying ground near by, where the dead received Christian sepulture.

S. E. Wicks was miller for the Indians, and his mill, erected by the government, was situated about two miles back from the Missouri valley, on Musketo creek.

The'Pottawattamies, while in Iowa, did not make any very rapid progress in the arts of civilization. Their squaws cultivated some small patches of corn, but the men and boys spent nearly all their time in hunting. Game was then plenty, and even the Buffalo and Elk were found east of the Missouri river. The Indians remained here until 1846-7, when they sold ont their possessions, by treaty dated June 5, 1846, and removed to Kansas, where they are still located.

Their departure made way for the advent of the followers of Joseph ${ }^{2}$ Smith. That leader of the greatest popular religious delusion of our century, having been killed at Nauvoo, in 1844 , his followers were, in the course of a year or two afterwards, expelled from the state of Illinois. Turning their faces westward they crossed the state of Iowa and seated themselves on the borders of the Missouri river. Brigham ${ }^{\prime}$ Young, with the head men of the church, halted, in 1846, at a place then known as Winter ${ }^{V}$ Quarters, on the west side of the river, where he remained until the following spring. Then, starting westward again, he moved on to the site now known as Salt Lake City, at which place he arrived on the 24th day of July, 1847, and established there the head-quarters and chief temple of the church of Latter Day Saints.

But the great body of the Mormons remained on the east. side of the Missouri river, and mainly within the limits of the present county of Pottawattamie - Winter Quarters, now Florence, in Nebraska, having been nearly deserted, although remaining an important outfitting point for the numerous par- 
ties that were constantly starting thence to the new possessions of the church in Utah. Many of the emigrants, from Nauroo, arrived early enough in the summer of 1846 to plant and secure crops that season, and many more came on in the succeeding fall and winter. They spread themselves rapidly over the county, and into some of the adjoining counties, locating themselves among the groves, and along the numerous beautiful streams of clear, pure, water that traverse western Iowa. The timber covering the bluffs and skirting the water courses, hitherto frequented only by the Indian, the elk, and deer, was ruthlessly cut down and converted into log cabins for the accommodation of the new comers; and where these could not be secured, holes and caves were dug in the hillsides, for the purpose of securing protection from the keen blasts of the prairies.

The valley of Indian creek, with the adjacent bluffs and the high table land stretching westward to the Missouri river, was, from the first, the centre and controlling head of this new community. Here a village of log buildings speedily sprang up, numbering its population by thousands, and bere their mammoth tabernacle was erected, built also of logs, and large enough to accommodate within its ample space at least a thousand worshippers. Over this community Orson Hyde, priest, writer, editor, and lawyer, was installed as the president of the quorum of twelve, and here his people dwelt, for many months, unmolested and undisturbed by the surgings and strifes of the outside world. No whistle of the locomotive disturbed their slumbers; not even the echo of the stage driver's horn was heard in their valleys, for not yet had tho Western Stage Company penetrated, with their coaches, to this far off land. For whatever information these people gained, in the way of letters and papers, from the outside world, they were indebted to special messengers from a post office in Missouri, more than a hundred miles distant. To their village they gave the name of Kanesville, in honor of Col. Kane, of Pennsylvania, who visited them during the early months of their sojourn, and who then, and in subsequent 
years, proved their true friend. Its location and limits were identical with the territorial limits of Conncil Blnffs.

For over four years the village of Kanesville, together with the entire county of Pottawattamie, and, to a certain extent, one or two adjoining counties, remained under the exclusive control of the Mormons. They guided public sentiment, controlled the elections, and filled all the offices of trust in the gift of the people. Representatives of their faith sat in at least two General Assemblies, and it is said to have been owing to their influence that the peculiar provision of the Code of Iowa, in relation to prosecution for adultery, was adopted. At any rate, it is certain that their ideas in relation to a plurality of wives were, to some extent, at least, practised by not a few of the Mormon leaders, with entire impunity, while residing in this state.

These people were then, as they have rrequently been since, charged with being hostile to the general government; but when they were appealed to in 1846 , to raise a battalion for service in the Mexican war, they promptly responded, and marched, about five hundred strong, under command of Col. Vlark, through the northern states of Mexico, taking part in several battles, and finally closing their campaign in California, where many of them engaged in mining, and secured handsome fortunes. Among the latter number was Mr. William Garner, who returned to Kanesville, and still resides in the county, where he is known as one of its most wealthy and public spirited citizens. It is claimed, with good show of reason, that the gold in the banks and waters of the Sacramento was first discovered by one or more members of this battalion, after their arrival in California.

The extent of the Mormon population of the county was probably larger in 1848 than in any subsequent year, but the state census of 1849, after many had left for Utah, shows it to have been at that time six thousand five hundred and fiftytwo, and in 1850 , by the national census, it reached seven thousand eight hundred and twenty-eight. The limits of the county were then, however, much larger than at present. It 
had first acquired separate organization in September, 1848. Its first clerk was James Sloan; its first county commissioners were A. H. 'Perkins, David D. Yearsley, and George 'Coulson ; and its first county judge, elected in 1851 , was T.'Burdick. The first term of the district court was held on the 5th of May, 1851, James Sloan presiding as district jndge. Evan M.'Green was clerk, and Alexander M'Rae, sheriff. The records of this term of the court are a great curiosity, in their way. The clerk seems to have discharged his duties with conscientious fidelity, and recorded at full length the entire proceedings of the court, including the testimony of witnesses, the arguments of counsel, and the charge of the judge. Sloan was a native of Ireland, and a Mormon, as were all the officials named above, and many anecdotes are told of his eccentricities and mother wit, while on the bevch. He resigned, after holding the office abont a year, and was succeeded by Judge "Bradford, appointed to the place by the governor, who filled the office until his successor, S. H.Riddle, was elected by the people, but the latter did not come upon the bench until the Mormon rule was passing away. Orson Hyde was one of the first attorneys admitted to practise before Judge Sloan's court.

Evan M. Green was the first postmaster at Kanesville. He received his commission in 1848 , but it was some time before regular mail service was established between it and the nearest post office in Missouri. And it was four or five years later before mails began to arrive regularly across the state from the east. In the same year Orsou Hyde established the Frontier Guardian, which continued to be published until 1852. It was edited by Hyde, himself, assisted during a part of the time by A. C.'Ford, and was primarily devoted to the defense and spread of the doctrines and practises of the Mormon church. It generally favored the whigs in politics, but the political faith, both of Hyde and his followers, sat rather loosely on their shoulders, and their votes were commonly cast in favor of whichever party seemed likely to show them the most favors. Candidates for office frequently made 
political pilgrimages across the prairies to this Mecca of the Missouri, for the purpose of winning the votes of this secluded and peculiar people. A story was long prevalent that the office of the Fuardian was furnished to Hyde as a reward for an almost unanimous vote which he caused to be cast for a particular eandidate for congress at the election in 1848; but in some way the poll books of the election were not forthcoming when the canvassing board met to make their returns. The first representative from the county to the General Assembly was Mr. Henry' Miller, of 'Kanesville; the second, Archibald 'Bryant; and the first senator, Hadley D.'Johnson, the two latter having been elected in 1852 .

With the advent of gold mining on the Pacific slope, began that tremendous rush of overland emigration, which for several succeeding years formed a notable feature in the history of the western country. It commenced in 1849 , increased to vast proportions in 1850 , and in 1851 crowded all the ferries, and during the summer month, filled all the valleys that intervened between the "Father of Waters" and the summit of the passes over the Rocky mountains. The settlements of the Mormons on the Missouri lay directly on the route of this tide of gold seekers, and soon their pastoral habits and peacefnl ways, their quiet gatherings and primitive sports, were rudely broken in upon and sadly marred by the rough spirits who scoffed at their religious pretensions, and laughed at their credulons faith. The village of Kanesville was the general rendezvous of all who crossed the state of Iowa, on their way to the new Ophir of the west. Its valleys were filled with their long lines of white canvas-covered wagons, and almost numberless droves and teams of oxen, mules, and horses; and its streets thronged with as rough and hardy a crowd of men as ever set out to seek their fortunes in any land, east or west. With them came also traders, dealers and venders of intoxicating drinks, gamblers, horse thieves, and desperate characters of every description, and soon the place was transformed into a very pandemonium of iniquity. Every available building was ere long converted into a gambling or 
drinking hall, and eommonly both, and erime of all kinds ran riot. The Sabbath was unobserved, and almost unknown, and except the gatherings in the Mormon tabernacle, over which Hyde presided, the voice of religion was silent, either to protect the innocent or punish the guilty. More than one poor fellow, at that early day and in subsequent years, was strung up by the neck to the most convenient tree, at the command of self-constituted vigilance committees. Nor was the evil abated when the returning miners made their appearance from the Pacific coast. They brought with them an abundance of the shining ore, and this seemed rather to increase the rage for gambling and drinking that so universally prevailed among the Gentile population, and which had wrought such demoralization among the earlier settlers.

The time had now fully come for the Mormons to follow their great leader to the happy valley among the mountains of Utah. Many had already taken their departure for the land of promise, while fresh trains of newly converted disciples from the old world and the new, had pressed on to the dominions of Brigham. So while Hyde's followers in Iowa had been gradually diminishing in number, those of Brigham, at Salt Lake, had been rapidly increasing. Finally, in 1852, the order came, and the word went round, that all true believers in the creed of Joseph ${ }^{2}$ Smith, as taught by his vicegerent, Brigham Young, should gather around the great central temple in Utah. Then came the harvest of the Gentiles. They swarmed into Kanesville, and into all the settlements of the faithful throughout the county. Farms were sold to them for a few hundred dollars; claims were bargained off for a span of horses or wagon; lots in Kanesville were exchanged for a yoke of oxen, and cabins and store rooms for a few articles of furniture and provisions for the journey. During all the spring and summer of 1852 the work of selling out and removal went forward, and long trains of the pilgrims covered all the roads up the Platte valley and across the Larimie plains, as they wended their way to the City of the Saints. This migra- 
tion continued with diminished volume during several succeeding years, until all the believers in the $e^{r}$ Mormon faith, who were willing to acknowledge Brigham' Young as the true successor of their first prophet and leader, had left the country.

Many of these people have since occupied prominent positions in the Mormon hierarchy, and one of Brigham's favorite concubines was formerly well known in Council Bluffs, as a young lady of decided beauty and accomplishments. A few of the prominent citizens of the county, who had formerly been numbered among 'Hyde's disciples, abjured the faith altogether, and remaining here have since proved themselves most worthy citizens; while others, refusing to recognise Brigham Young as their prophet, have adhered to the fortunes of Joseph Smith, jr. These latter have ratherincreased than diminished in numbers, during the last few years, and they now have a regular religious organization in several of the western counties, and a church in the city of Council Bluffs. They altogether repudiate the doctrine of a plurality of wives, and are a well meaning, industrions, and respectable class of people.

With the year 1852-3, the Mormon predominance in Pottawattamie county practically ceased, and within a year or two thereafter, the "Gentiles," by which term all new comers not Mormons were known, aequired entire control of its destinies. How they prospered, together with a few incidents connected with the subsequent history of the county, will be related in a future paper.

[TO BE CONTINUED.] 
Copyright of Annals of Iowa is the property of State of Iowa, by \& through the State Historical Society of Iowa and its content may not be copied or emailed to multiple sites or posted to a listserv without the copyright holder's express written permission. However, users may print, download, or email articles for individual use. 